\title{
PENGARUH UKURAN PERUSAHAAN, ROA, DAR, DAN REPUTASI AUDITOR TERHADAP AUDIT DELAY
}

\section{THE IMPACT OF COMPANY SIZE, ROA, DAR AND AUDITOR'S REPUTATION ON AUDIT DELAY}

\author{
Mimelientesa Irman \\ Sekolah Tinggi Ilmu Ekonomi Pelita Indonesia \\ teshairman@ymail.com
}

\begin{abstract}
This study aims to analyze the factors that affect audit delay on manufacturing companies listed in Indonesia Stock Exchange (BEI). This test uses multiple linear regression model. Sample of this study are 20 companies in manufacturing sector. Observation period is 6 years from 2010 to 2015. Independent variables in this study consisted of company size, profitability (ROA), solvency (DAR), and auditor's reputation which tested its influence on audit delay as dependent variable. The results showed that company size, profitability (ROA), solvency (DAR), and auditor's reputation significantly influence on audit delay of manufacturing companies listed in Indonesia Stock Exchange (BEI) period 2010 until 2015
\end{abstract}

Keywords: Firm size, ROA, DAR, Reputation Auditor and Audit Delay

\section{ABSTRAK}

Penelitian ini bertujuan untuk menganalisis faktor-faktor yang mempengaruhi audit delay pada perusahaan manufaktur yang terdaftar di Bursa Efek Indonesia (BEI). Pengujian ini menggunakan model regresi linier berganda. Sampel dari penelitian berjumlah 20 perusahaan yang bergerak dalam bidang manufaktur. Periode pengamatan adalah 6 tahun dari tahun 2010 sampai dengan 2015. Variabel independen yang digunakan antara lain ukuran perusahaan, profitabilitas (ROA), solvabilitas (DAR), dan reputasi auditor yang diuji pengaruhnya terhadap variabel dependen yaitu Audit Delay. Hasil pengujian menunjukkan bahwa ukuran perusahaan, profitabilitas (ROA), solvabilitas (DAR), dan reputasi auditor berpengaruh signifikan terhadap audit delay pada perusahaan perusahaan manufaktur yang terdaftar di Bursa Efek Indonesia (BEI) periode 2010-2015.

Kata kunci : Ukuran Perusahaan, ROA, DAR, Reputasi Auditor dan Audit Delay

\section{PENDAHULUAN}

Laporan keuangan merupakan salah satu sumber informasi yang berperan penting dalam pengambilan keputusan dan berfungsi sebagai media komunikasi yang menyampaikan berbagai informasi dan pengukuran secara ekonomis. Menurut Ikatan Akuntansi Indonesia (IAI, 2009), tujuan dari laporan keuangan adalah untuk menyediakan informasi yang menyangkut posisi keuangan, kinerja serta perubahan posisi keuangan suatu perusahaan yang bermanfaat bagi sejumlah pengguna.

Perkembangan pasar modal di Indonesia berdampak pada peningkatan permintaan akan audit laporan keuangan. Setiap perusahaan yang go public diwajibkan untuk menyampaikan Laporan keuangan tahunan yang dimuat dalam Laporan Tahunan disusun sesuai dengan Standar Akuntansi Keuangan di 
Indonesia dan telah diaudit oleh Akuntan.

Laporan keuangan dimaksud memuat pernyataan mengenai pertanggungjawaban atas laporan keuangan sebagaimana diatur dalam peraturan perundangundangan di sektor Pasar Modal yang mengatur mengenai tanggung jawab Direksi atas laporan keuangan atau peraturan perundangundangan di sektor Pasar Modal yang mengatur mengenai laporan berkala Perusahaan Efek dalam hal Emiten merupakan Perusahaan Efek. (Salinan Surat Edaran OJK Nomor : 30/SEOJK.04/2016). Hasil audit atas perusahaan publik mempunyai konsekuensi dan tanggung jawab yang besar, adanya tanggung jawab yang besar ini memacu seorang auditor untuk bekerja lebih profesional, salah satu kriteria profesionalisme dari seorang auditor adalah ketepatan waktu penyampaian laporan auditnya.

Ketepatan waktu penyampaian laporan keuangan sebelummnya diatur oleh Bapepam-LK. Bapepam-LK menetapkan bahwa penyampaian laporan keuangan selambat-lambatnya pada akhir bulan ketiga setelah tanggal laporan keuangan tahunan (90 hari) (dalam Surat Keputusan Ketua Bapepam-LK No.36/PM/2003, No. 1 Peraturan X.K.2).

Akan tetapi, pada akhir Desember 2012, pemerintah berkomitmen untuk mengalihkan tugas BAPEPAM-LK ke OJK (Otoritas Jasa Keuangan). Hal ini didasarkan pada Undang-Undang Nomor 21 Tahun 2011 yang berisi "Terhitung mulai tanggal 31 Desember 2012, Tugas dan Fungsi Bapepam-LK akan berpindah ke Otoritas Jasa Keuangan (OJK)". Sejak perpindahan itu, penyampaian laporan keuangan yang ditentukan oleh OJK adalah paling lambat pada akhir bulan keempat setelah tahun buku berakhir (dalam Peraturan Nomor 29/POJK.04/2016 Bab III, Pasal 7, hlm.5).

Periode waktu dari tanggal tutup buku laporan keuangan sampai tanggal pemberian opini dan laporan audit sering disebut sebagai Audit Delay. Dengan kata lain Audit Delay adalah lamanya hari yang dibutuhkan auditor untuk menyelesaikan pekerjaan audit, yang diukur dari tanggal penutupan tahun buku hingga tanggal diterbitkannya laporan audit menurut Prabandari dan Rustiana (2007).

Ketentuan sanksi mengenai keterlambatan penyampaian laporan keuangan audit dinyatakan dalam Peraturan Otoritas Jasa Keuangan Nomor 29/POJK.04/2016 Bab VI pasal 19-21.

Mengingat pentingnya ketepatan waktu pelaporan keuangan bagi pembuat keputusan, dimana audit delay menjadi salah satu faktor yang mempengaruhi terlambatnya pelaporan keuangan, menjadikan audit delay serta faktor-faktor yang mempengaruhinya dapat menjadi salah satu objek yang dapat diteliti.

Menurut Rochimawati (2008), Kartika (2009) dan Noverta (2012) terdapat banyak faktor yang mempengaruhi audit delay, seperti ukuran perusahaan, umur perusahaan, laba atau rugi perusahaan, profitabilitas, solvabilitas, opini audit, reputasi auditor dan reputasi KAP.

Faktor internal yang paling mendasar adalah ukuran perusahaan. Menurut penelitian Ristin, Dwi Marta dan Wirawati (2016), ukuran 
perusahaan dapat berpengaruh terhadap audit delay. Sementara itu, hasil penelitian Candra (2015), Petronila (2007) dan Kartika (2009), ukuran perusahaan tidak berpengaruh terhadap audit delay. Diperkirakan, ukuran perusahaan tidak berpengaruh terhadap audit delay karena sampel merupakan perusahaan terdaftar di BEI yang diawasi investor, pengawas permodalan, dan pemerintah.

Faktor lain yang berpengaruh terhadap audit delay adalah profitabilitas. Hasil penelitian Lianto dan Kusuma (2010) menemukan bahwa profitabilitas berpengaruh terhadap audit delay. Namun, hasil penelitian Candra (2015) \& Kartika (2009) menunjukan bahwa profitabilitas tidak berpengaruh signifikan terhadap audit delay. Hasil penelitian ini menemukan bahwa perusahaan yang mengalami tingkat keuntungan baik kecil maupun besar cenderung untuk mempercepat proses auditnya.

Selain faktor profitabilitas, diduga faktor solvabilitas juga berpengaruh terhadap audit delay. Menurut Fika Ristin (2016) dan Candra (2015), semakin banyak jumlah hutang yang dimiliki suatu perusahaan maka akan semakin besar pula tekanan yang dirasakan perusahaan tersebut untuk menyediakan laporan keuangan lebih cepat untuk para kreditor. Namun, hasil penelitian Yulianti (2011), menunjukkan bahwa tidak ada pengaruh yang signifikan dari tingkat solvabilitas terhadap audit delay.

Faktor lain yang mempengaruhi audit delay adalah reputasi auditor. Kualitas auditan berpengaruh terhadap kredibilitas laporan keuangan perusahaan go public. Dari penelitian yang sudah ada, reputasi tinggi auditor berpengaruh terhadap audit delay (Setiawan, 2013). KAP yang masuk dalam big four ternyata mempunyai pengaruh secara signifikan terhadap jangka waktu penyampaian laporan audit.

Berdasarkan paparan beberapa penelitian terdahulu yang sudah dilakukan di atas, maka penelitian ini bermaksud mengkaji lebih jauh mengenai faktor-faktor yang mempengaruhi audit delay. Meskipun telah banyak dilakukan penelitian tentang audit delay pada perusahaan yang terdaftar di BEI, namun masih banyak perbedaan hasil. Hasil penelitian tersebut bisa beragam dikarenakan perbedaan dalam pengambilan variabel independen, perbedaan sampel yang diteliti, perbedaan periode pengamatan atau perbedaan dalam metodologi statistik yang digunakan.

Rumusan Masalah: Bagaimana pengaruh ukuran perusahaan, tingkat profitabilitas (ROA), tingkat solvabilitas (DAR), dan reputasi auditor terhadap audit delay pada perusahaan manufaktur yang terdaftar di BEI tahun 2010-2015?

Tujuan penelitian: Untuk menganalisis pengaruh ukuran perusahaan, tingkat profitabilitas (ROA), tingkat solvabilitas (DAR), dan reputasi auditor terhadap audit delay pada perusahaan manufaktur yang terdaftar di BEI tahun 2010-2015.

Menurut Arens et al. (2010), auditing adalah proses pengumpulan dan evaluasi bahan bukti tentang informasi yang dapat diukur mengenai suatu entitas ekonomi untuk menentukan dan melaporkan kesesuaian 
informasi dengan kriteria yang telah ditetapkan.

Standar auditing merupakan pedoman umum untuk membantu auditor dalam memenuhi tanggung jawab dan profesionalisme mereka dalam mengaudit laporan keuangan. Standar auditing juga mencakup pertimbangan dalam kualitas profesional seperti kompetensi dan independensi, persyaratan pelaporan, dan bukti (Arens, et al, 2010).

Ketepatan waktu penerbitan laporan keuangan auditan merupakan hal yang sangat penting khususnya untuk perusahaan-perusahaan public yang menggunakan pasar modal sebagai salah satu pendanaan. Namun auditor memerlukan waktu yang cukup untuk dapat mengumpulkan bukti-bukti kompeten yang dapat mendukung opininya (Destiana, 2011).

Menurut Rochimawati (2008) ukuran perusahaan adalah suatu ukuran perusahaan yang menunjukkan besar kecilnya perusahaan. Ukuran perusahaan ditandai dengan beberapa ukuran antara lain total penjualan, total asset, log size, jumlah pegawai, nilai pasar perusahaan, dan nilai buku perusahaan. Penelitian ini menggunakan log total aset yang dimiliki perusahaan sebagai ukuran perusahaan.

Profitabilitas adalah kemampuan perusahaan dalam menghasilkan laba atau keuntungan selama periode tertentu pada tingkat penjualan, aset, dan modal saham tertentu. Dalam penelitian ini, indikator yang digunakan untuk mengukur tingkat profitabilitas adalah Return On Assets (ROA), rasio ini mengukur kemampuan perusahaan menghasilkan laba berdasarkan tingkat aset tertentu (Kinanti, Irsalina:2012).
Solvabilitas perusahaan dalam penelitian ini diukur dengan membandingkan jumlah utang (baik jangka pendek ataupun jangka panjang) dengan jumlah aktiva (Rachmawati, 2008). Angka perbandingan tersebut dinyatakan dalam Debt to Assets Rasio (DAR). Tujuan digunakan Debt to Assets Rasio dikarenakan rasio ini mengindikasikan kesehatan perusahaan.

Kualitas auditor dapat diketahui dari besarnya perusahaan audit yang melaksanakan pengauditan laporan keuangan tahunan, bersandar pada apakah Kantor Akuntan Publik (KAP) berafiliasi dengan the big four atau tidak (Febrianty 2011). Yang termasuk dalam KAP the big four adalah Deloitte \& Touche, Ernst \& Young, Price Water House Coopers dan KPMG.

Hipotesis dalam penelitian ini dapat dirumuskan sebagai berikut: (1) Ukuran perusahaan berpengaruh positif terhadap audit delay, (2) Tingkat profitabilitas berpengaruh positif terhadap audit delay, (3) Tingkat solvabilitas berpengaruh positif terhadap audit delay, dan (4) Reputasi auditor berpengaruh positif terhadap audit delay.

\section{METODE PENELITIAN}

Populasi dalam penelitian ini adalah perusahaan manufaktur yang terdaftar di Bursa Efek Indonesia (BEI) periode 2010-2015. Pengambilan waktu tersebut guna melihat konsistensi hasil penelitian dari tahun ke tahun. Ada sekitar 143 perusahaan manufaktur yang listing di BEI. Dari 143 populasi yang ada, selanjutnya diambil sampel menggunakan metode purposive sampling, yaitu penarikan sampel dengan pertimbangan tertentu 
disesuaikan pada kepentingan dan tujuan penelitian.. Alasan menggunakan metode purposive sampling dengan pertimbangan agar sampel yang diteliti memenuhi kriteria untuk diuji dan menghindari bias yang disebabkan oleh adanya perbedaan yang ekstrim. Jadi, jumlah sampel yang akan diteliti adalah sebanyak 20 perusahaan.

Metode analisis data akan dilakukan dengan bantuan aplikasi komputer program SPSS (Statistical Package For Social Science) versi 20. Adapun model regresi linier berganda yang digunakan sebagai berikut:

$$
Y=\alpha+\beta_{1} X_{1}+\beta_{2} X_{2}+\beta_{3} X_{3}+\beta_{4} X_{4}
$$

Notasi :

$$
\begin{array}{ll}
\mathrm{Y} & =\text { Audit delay } \\
\alpha & =\text { Konstanta } \\
\mathrm{X}_{1} & =\text { Ukuran Perusahaan } \\
\mathrm{X}_{2} & =\text { ROA } \\
\mathrm{X}_{3} & =\text { DAR } \\
\mathrm{X}_{4} & =\text { Reputasi Auditor } \\
\beta_{1} \beta_{2} \beta_{3} \beta_{4} & =\text { Koefisien regresi }
\end{array}
$$

masing-masing variabel independen

Analisis deskriptif adalah analisis yang bertujuan untuk membuat deskripsi, gambaran atau lukisan secara sistematis, factual dan akurat mengenai fakta-fakta, sifat-sifat serta hubungan antar fenomena yang diselidiki.

Salah satu syarat untuk bisa menggunakan persamaan regresi linier berganda adalah terpenuhinya uji asumsi klasik. Tujuan pengujian asumsi klasik adalah untuk mengetahui apakah hasil estimasi regresi yang dilakukan terbebas dari bias yang mengakibatkan hasil regresi yang diperoleh tidak valid dan akhirnya hasil regresi tersebut tidak dapat dipergunakan sebagai dasar untuk menguji hipotesis dan penarikan kesimpulan. Uji asumsi klasik terdiri dari uji normalitas, uji multikolinearitas, uji autokorelasi dan uji heteroskedastisitas.

Uji t digunakan untuk mengetahui apakah secara parsial variabel independen berpengaruh secara signifikan terhadap variabel dependen (Priyatno, 2012). Uji hipotesis dalam penelitian ini dilakukan dengan tingkat signifikansi sebesar 5\% dengan derajat kebebasan $\mathrm{df}=(\mathrm{n}-\mathrm{k}-1)$, dimana $\mathrm{n}=$ jumlah observasi dan $\mathrm{k}=\mathrm{jumlah}$ variabel. Dasar pengambilan keputusan dapat dilihat dari nilai $t_{\text {hitung }}$ yang akan dibandingkan dengan $t_{\text {tabel. }}$. Jika $t_{\text {hitung }}>$ $\mathrm{t}_{\text {tabel, }}$ maka $\mathrm{H}_{1}$ diterima dan $\mathrm{H}_{0}$ ditolak. Begitu pula sebaliknya.

Tujuan dari uji ini untuk mengetahui pengaruh variabel independen secara bersama-sama terhadap variabel dependen dengan melihat nilai signifikansi $F$. Uji hipotesis dalam penelitian ini dilakukan dengan tingkat signifikansi sebesar 5\%. Dasar pengambilan keputusan dapat dilihat dari nilai $F_{\text {hitung }}$ yang akan dibandingkan dengan $\mathrm{F}_{\text {tabel. }}$. Jika $\mathrm{F}_{\text {hitung }}>$ $\mathrm{F}_{\text {tabel, }}$ maka $\mathrm{H}_{1}$ diterima dan $\mathrm{H}_{0}$ ditolak. Begitu pula sebaliknya.

Uji koefisien determinasi bertujuan untuk mengetahui seberapa besar kemampuan variabel independen menjelaskan variabel dependen (Nugroho, 2005). Nilai koefisien determinasi dapat dilihat dari adjusted $\mathrm{R}^{2}$ yang berkisar antara 0 sampai dengan $1 \%$. Jika nilainya mendekati 1 maka semakin baik.

\section{HASIL DAN PEMBAHASAN}

Hasil Uji Regresi Linear Berganda

Bentuk persamaan regresi linier dalam penelitian ini sebagai berikut : 


$$
\begin{gathered}
Y=72,897-6,199 X_{1}+0,240 X_{2}+ \\
25,795 X_{3}-7,619 X_{4}
\end{gathered}
$$

Dengan persamaan regresi linier di atas dapat dijelaskan bahwa :

Konstanta $\quad(\alpha)$ sebesar $\quad 72,897$ memperlihatkan arah hubungan variabel independen yang positif terhadap audit delay. Artinya apabila $\mathrm{X}_{1}, \mathrm{X}_{2}, \mathrm{X}_{3}, \mathrm{X}_{4}$ dan $\mathrm{X}_{5}$ bernilai nol (0), maka audit delay bernilai 72,897 .

Koefisien regresi variabel $\mathrm{X}_{1} \quad\left(\beta_{1}\right)$ bernilai $-6,199 \mathrm{E}-008$. Hal ini menunjukkan bahwa ukuran perusahaan memiliki arah hubungan yang negatif sejauh 6,199E-008 terhadap audit delay. Dengan kata lain, semakin besar ukuran perusahaan maka audit delay akan semakin pendek, demikian pula sebaliknya. Dengan asumsi variabel lain bernilai tetap, dapat diartikan bahwa setiap kenaikan ukuran perusahaan sebesar 1 akan menyebabkan penurunan pada audit delay sebesar 6,199E-008.

Koefisien regresi variabel $\mathrm{X}_{2}$ $\left(\beta_{2}\right)$ bernilai 0,240 . Hal ini menunjukkan bahwa ROA memiliki arah hubungan yang positif sejauh 0,240 terhadap audit delay. Dengan kata lain, semakin besar ROA maka audit delay akan semakin panjang, demikian pula sebaliknya. Dengan asumsi variabel lain bernilai tetap, dapat diartikan bahwa setiap kenaikan ROA sebesar 1 akan menyebabkan kenaikan pada audit delay sebesar 0,240.

Koefisien regresi variabel $\mathrm{X}_{3}$ $\left(\beta_{3}\right)$ bernilai 25,795. Hal ini menunjukkan bahwa DAR memiliki arah hubungan yang positif sejauh 25,795 terhadap audit delay. Dengan kata lain, semakin besar DAR maka audit delay akan semakin panjang, begitu sebaliknya. Dengan asumsi variabel lain bernilai tetap, dapat diartikan bahwa setiap kenaikan DAR sebesar 1 akan menyebabkan kenaikan pada audit delay sebesar 25,795.

Koefisien regresi variabel $\mathrm{X}_{4}\left(\beta_{4}\right)$ bernilai $-7,619$. Hal ini menunjukkan bahwa ukuran perusahaan memiliki arah hubungan yang negatif sejauh 7,619 terhadap audit delay. Dengan kata lain, semakin besar reputasi auditor maka audit delay akan semakin pendek, begitu sebaliknya. Dengan asumsi variabel lain bernilai tetap, dapat diartikan bahwa setiap kenaikan reputasi auditor sebesar 1 akan menyebabkan penurunan pada audit delay sebesar 7,619.

Nilai standard error $(\varepsilon)$ didapatkan sebesar 8,651.

Uji Hipotesis Analisis Parsial (Uji t)

Berdasarkan tabel di atas, uji parsial dari hasil penelitian ini adalah: Hipotesis pertama $\left(\mathrm{H}_{1}\right)$ menunjukkan bahwa $t_{\text {hitung }}(-2.328)>t_{\text {tabel }}(1,983)$ dan signifikansi $(0,022)<\alpha(0,050)$, Oleh karena itu maka hipotesis pertama $\left(\mathrm{H}_{1}\right)$ diterima. Sehingga dapat disimpulkan bahwa ukuran perusahaan berpengaruh negatif terhadap audit delay.

Hipotesis kedua

menunjukkan bahwa $t_{\text {hitung }}(2.296)>$ $\mathrm{t}_{\text {tabel }}(1,983)$ dan signifikansi $(0,024)<\alpha$ $(0,050)$, oleh karena itu maka hipotesis kedua $\left(\mathrm{H}_{2}\right)$ diterima. Sehingga dapat disimpulkan bahwa ROA berpengaruh positif terhadap audit delay.

$$
\text { Hipotesis ketiga }\left(\mathrm{H}_{3}\right)
$$

menunjukkan bahwa $t_{\text {hitung }}(4,877)>$ $\mathrm{t}_{\text {tabel }}(1,983)$ dan signifikansi $(0,000)<\alpha$ $(0,050)$, oleh karena itu maka hipotesis ketiga $\left(\mathrm{H}_{3}\right)$ diterima. Sehingga dapat disimpulkan bahwa DAR berpengaruh positif terhadap audit delay.

Hipotesis keempat $\left(\mathrm{H}_{4}\right)$ menunjukkan bahwa $t_{\text {hitung }}(-2,777)>t_{\text {tabel }}(1,983)$ dan 
signifikansi $(0,009)<\alpha(0,050)$, oleh karena itu maka hipotesis kelima $\left(\mathrm{H}_{4}\right)$ diterima. Sehingga dapat disimpulkan bahwa reputasi auditor berpengaruh negatif signifikan terhadap audit delay.

\section{Uji Hipotesis Analisis Simultan}

\section{(Uji F)}

Berdasarkan tabel di atas, hasil pengujian hipotesis simultan $\left(\mathrm{H}_{6}\right)$ menunjukkan bahwa $t_{\text {hitung }}(8,426)>$ $\mathrm{t}_{\text {tabel }}(2,457)$ dan signifikansi $(0,000)<\alpha$ $(0,050)$, oleh karena itu maka hipotesis simultan $\left(\mathrm{H}_{5}\right)$ diterima. Sehingga dapat disimpulkan bahwa ukuran perusahaan, ROA, DAR dan reputasi auditor berpengaruh signifikan terhadap audit delay.

\section{Koefisien Determinasi $\left(\mathbf{R}^{\mathbf{2}}\right)$}

nilai adjusted $\mathrm{R}$ square adalah sebesar 0,321. Hal ini menunjukkan bahwa $32,10 \%$ perubahan pada audit delay diterangkan oleh variabel-variabel independen (ukuran perusahaan, ROA, DAR dan reputasi auditor) yang digunakan dalam model penelitian ini. Sedangkan sisanya $67,90 \%$ diterangkan oleh variabel lain yang tidak dimasukkan dalam penelitian.

\section{Pengaruh ukuran perusahaan terhadap audit delay}

Penerimaan terhadap hipotesis pertama ini menunjukkan bahwa ukuran perusahaan memang secara signifikan berpengaruh negatif signifikan terhadap lamanya waktu penyelesaian laporan audit.

$$
\text { Hasil penelitian ini }
$$
mengindikasikan bahwa semakin besar ukuran perusahaan yang diukur dari total aset atau kekayaan yang dimiliki oleh suatu perusahaan akan mempercepat waktu penyelesaian laporan audit. Hal ini disebabkan karena perusahaan besar umumnya sudah memiliki sistem yang canggih, sumber daya manusia yang lebih banyak dan kompeten dalam menyelesaikan laporan audit perusahaan serta pengendalian internal yang baik sehingga memudahkan perusahaan untuk memberikan data kepada auditor. Selain itu, perusahaan yang berskala besar cendrung memiliki dana yang lebih banyak untuk mengontrak auditor independen yang kompeten sehingga bisa memberikan insentif lebih besar.

Berpengaruhnya ukuran perusahaan terhadap audit delay dalam penelitian ini sesuai dengan hasil yang dilakukan oleh Ristin, Dwi Marta dan Wirawati (2016).

Namun, hasil penelitian Candra (2015), Petronila (2007) dan Kartika (2009) menunjukkan bahwa ukuran perusahaan tidak berpengaruh terhadap audit delay. Diperkirakan, ukuran perusahaan tidak berpengaruh terhadap audit delay karena sampel merupakan perusahaan terdaftar di BEI yang diawasi investor, pengawas permodalan, dan pemerintah. Atas dasar itu, perusahaan dengan asset besar maupun kecil mempunyai kemungkinan yang sama dalam menghadapi tekanan atas penyampaian laporan keuangan.

\section{Pengaruh ROA terhadap audit delay}

Penerimaan terhadap hipotesis kedua ini menunjukkan bahwa tingkat profitabilitas yang dihitung dengan rasio ROA (Return On Assets) memang secara signifikan berpengaruh positif terhadap lamanya waktu penyelesaian laporan audit.

Hasil penelitian ini mengindikasikan bahwa besarnya rasio ROA (Return On Assets) yang diukur dari kemampuan perusahaan dalam memanfaatkan asset untuk 
menghasilkan laba akan memperlambat waktu penyelesaian laporan audit. Hal ini disebabkan karena semakin besar kemampuan perusahaan untuk menghasilkan laba, maka transaksi penjualan yang ada dalam perusahaan tersebut akan semakin banyak. Dengan adanya laba yang besar, maka akan ada tuntutan dari pihak manajemen untuk mempercepat memberikan kabar baik kepada publik. Tapi disisi lain, auditor akan semakin berhati-hati dalam melihat setiap detail penjualan yang ada, apakah penjualan itu benar-benar terjadi atau hanya penjualan fiktif supaya perusahaan bisa menghasilkan laba. Karena kehati-hatian itulah yang membuat laporan audit akan lama selesai.

Berpengaruhnya tingkat profitabilitas khususnya rasio ROA terhadap audit delay dalam penelitian ini sesuai dengan hasil yang dilakukan oleh Lianto dan Kusuma (2010).

Namun, hasil penelitian Candra (2015) \& Kartika (2009) menunjukan bahwa profitabilitas tidak berpengaruh signifikan terhadap audit delay. Hasil penelitian ini menemukan bahwa perusahaan yang mengalami tingkat keuntungan baik kecil maupun besar cenderung untuk mempercepat proses auditnya.

\section{Pengaruh DAR terhadap audit delay}

Penerimaan terhadap hipotesis ketiga ini menunjukkan bahwa tingkat solvabilitas yang dihitung dengan DAR (Debt to Asset Ratio) memang secara signifikan berpengaruh positif terhadap lamanya waktu penyelesaian laporan audit.

Hasil penelitian ini mengindikasikan bahwa semakin besar DAR (Debt to Asset Ratio) yang diukur dari kemampuan perusahaan dalam melunasi utang maka waktu penyelesaian laporan audit akan semakin panjang. Hal ini disebabkan karena perusahaan yang memiliki DAR tinggi menggambarkan kondisi perusahaan yang kurang baik atau gagal dan meningkatkan fokus auditor bahwa laporan keuangan kurang reliable. Hal ini karena tingginya DAR secara normal berhubungan dengan tingginya risiko. Ini merupakan hasil dari kesehatan finansial perusahaan yang buruk dimana mungkin terjadi karena manajemen yang buruk dan fraud. Fokus auditor dalam hal ini akan membutuhkan waktu yang lebih lama dalam melaksanakan proses audit karena harus mengumpulkan alat bukti yang lebih kompeten untuk meyakinkan kewajaran laporan keuangannya.

Berpengaruhnya tingkat solvabilitas khususnya rasio DAR terhadap audit delay dalam penelitian ini sesuai dengan hasil yang dilakukan oleh Fika Ristin (2016), Candra (2015), Hardika dan Vega (2013).

Namun, hasil penelitian Yulianti (2011), menunjukkan bahwa tidak ada pengaruh yang signifikan dari tingkat solvabilitas terhadap audit delay. Yang artinya kemampuan perusahaan untuk memenuhi kewajiban untuk membayar utang-utangnya ternyata tidak mempunyai pengaruh yang signifikan terhadap lamanya proses penyampaian laporan auditan atas laporan keuangan.

Pengaruh Reputasi Auditor terhadap audit delay

Penerimaan terhadap hipotesis kelima ini menunjukkan bahwa reputasi auditor yang diukur dari adanya afiliasi dengan the big four atau tidak memang secara signifikan berpengaruh negatif 
terhadap lamanya waktu penyelesaian laporan audit.

Hasil penelitian ini mengindikasikan bahwa semakin besar reputasi auditor maka waktu penyelesaian laporan audit akan semakin pendek. Hal ini disebabkan karena KAP yang masuk the big four dengan yang non the big four memiliki karakteristik yang berbeda. KAP yang masuk the big four akan bekerja lebih profesional dari pada yang non the big four. KAP yang masuk big four biasanya memiliki auditor yang berpengalaman dan kompeten dalam bekerja sehingga penyampaian laporan auditan yang mereka buat akan jauh lebih efektif dan efisien. Hal ini terjadi karena KAP tersebut berusaha untuk menjaga reputasi mereka.

Berpengaruhnya reputasi auditor terhadap audit delay dalam penelitian ini sesuai dengan hasil yang dilakukan oleh Fika Ristin (2016), Setiawan (2016), Hardika dan Vega (2013). Sementara penelitian Andi Kartika (2009) menunjukkan bahwa reputasi auditor tidak berpengaruh terhadap audit delay.

Pengaruh ukuran perusahaan, ROA, DAR, dan reputasi auditor terhadap audit delay

Dari hasil pengujian hipotesis uji $\mathrm{F}$ dapat dikemukakan bahwa faktor internal (ukuran perusahaan, ROA, DAR) dan faktor external (reputasi auditor) yang dipilih dalam penelitian secara bersamaan memang berpengaruh signifikan terhadap lamanya penyelesaian laporan audit. Hasl penelitian ini mengindikasikan bahwa faktor ukuran perusahaan, ROA, DAR dari dalam perusahaan serta reputasi auditor dari luar perusahaan merupakan perhatian penting perusahaan dalam menerima laporan audit dari laporan auditor independen.

\section{PENUTUP \\ Kesimpulan}

Berdasarkan hasil penelitian dan pembahasan yang telah dilakukan, maka kesimpulan yang dapat diambil adalah sebagai berikut : (1) Hasil pengujian hipotesis pertama menunjukkan bahwa ukuran perusahaan secara parsial terbukti berpengaruh negatif signifikan terhadap audit delay sebagai dasar penyampaian laporan audit; (2) Hasil pengujian hipotesis kedua menunjukkan bahwa tingkat profitabilitas khususnya rasio ROA (Return On Assets) secara parsial terbukti berpengaruh positif signifikan terhadap audit delay sebagai dasar penyampaian laporan audit; (3) Hasil pengujian hipotesis ketiga menunjukkan bahwa tingkat solvabilitas khususnya DAR (Debt to Assets Ratio) secara parsial terbukti berpengaruh positif signifikan terhadap audit delay sebagai dasar penyampaian laporan audit; (4) Hasil pengujian hipotesis ke empat menunjukkan bahwa reputasi auditor secara parsial terbukti berpengaruh negatif signifikan terhadap audit delay sebagai dasar penyampaian laporan audit; dan (5) Hasil pengujian hipotesis simultan menunjukkan bahwa ukuran perusahaan, ROA, DAR, dan reputasi auditor secara simultan terbukti berpengaruh signifikan terhadap audit delay sebagai dasar penyampaian laporan audit.

Saran

Berdasarkan kesimpulan serta pembahasan hasil penelitian yang ada, 
maka saran yang dapat peneliti berikan adalah sebagai berikut:

1. Dalam pembuatan laporan terutama laporan audit, perusahaan disarankan untuk memberikan perhatian pada faktor internal (ukuran perusahaan, tingkat profitabilitas/ROA, tingkat solvabilitas/DAR) dan external (reputasi auditor) yang menjadi variabel independen dalam penelitian ini.

2. Bagi para auditor dan KAP penelitian ini bisa membantu mereka mengidentifikasi apa saja hal yang membuat pengerjaan laporan audit lama. Para auditor dapat mengoptimalkan kinerja dalam pembuatan laporan. Sedangkan KAP dapat bekerja sama dengan pihak-pihak yang lebih berkompeten supaya reputasi mereka tetap terjaga.

3. Para peneliti selanjutnya hendaklah menambahkan variabel independen yang diteliti. Karena hasil uji koefisien determinasi $\left(\mathrm{R}^{2}\right)$ menunjukkan bahwa variabel independen dalam penelitian ini hanya menjelaskan perubahan pada audit delay sebesar $32,10 \%$ sedangkan sebesar $67,90 \%$ dijelaskan oleh variabel lain di luar variabel yang digunakan dalam penelitian ini. Salah satu variabel yang dapat ditambahkan adalah umur perusahaan karena dari umur perusahaan bisa dilihat berapa lama perusahaan itu bisa bertahan dalam persaingan pasar.

\section{DAFTAR PUSTAKA}

Arens, Alvin A, Randal J. Elder, Mark

S. Beasley. 2010. Auditing and Assurance Services : An Integrated Approach 13th Edition, Pearson, Prentice Hall Inc.

BAPEPAM LK. 2003. Surat Keputusan Ketua Badan Pengawas Pasar Modal dan Lembaga Keuangan Nomor: Kep-36/PMK/2003.

Candra, Muliadi. 2015. Faktor-Faktor yang Mempengaruhi Audit Delay pada Perusahaan Manufaktur di Bursa Efek Indonesia. Skripsi. Universitas Islam Negeri Sultan Syarif Kasim Riau.

Dwi Marta Sanjaya, I Made. Ni Gusti Putu Wirawati. April 2016.Analisis Faktor-faktor yang Mempengaruhi Ketepatan Pelaporan Keuangan pada Perusahaan Manufaktur yang Terdaftar di BEI. Fakultas Ekonomi dan Bisnis Universitas Udayana (Unud), Bali, Indonesia.

Febrianty. 2011. Faktor-Faktor yang Berpengaruh Terhadap Audit Delay Perusahaan Sektor Perdagangan yang Terdaftar di Bursa Efek Indonesia Periode 2007-2009. Jurnal Ekonomi dan Informasi Akuntansi (Jenius). Vol. 1/ No. 3/ September.

Hardika, N.S \& Y. C. Vega G. 2013. Faktor-Faktor yang Mempengaruhi Audit Delay pada Perusahaan Publik di Bursa Efek Indonesia. Jurnal Bisnis dan Kewirausahaan. Vol. 9 (3) pp. 274-285. 
Ikatan Akuntan Indonesia. 2009. Standar Akuntansi Keuangan. Jakarta: Salemba Empat

Kartika, Andi. Maret 2009. Faktorfaktor yang Mempengaruhi Audit Delay di Indonesia (Studi Empiris pada Perusahaanperusahaan LQ 45 yang Terdaftar di Bursa Efek Jakarta). Fakultas Ekonomi Universitas Stikubank Semarang.

Kinanti, Irsalina. 2012. Pengaruh Faktor Internal Dan Eksternal Terhadap Audit Delay Pada Perusahaan Property Dan Real Estate Periode 2009-2011.

Lianto,N \& Budi Hartono Kusuma, 2010. " Faktor-Faktor Yang Berpengaruh Terhadap Audit Report Lag".Jurnal Bisnis dan Akuntansi Vol 12.

Noverta, Christian, Togasima dan Yulius Jogi Christiawan. 2014. Analisis FaktorFaktor yang Mempengaruhi Audit Report Lag pada Perusahaan yang Terdaftar di Bursa Efek Indonesia pada Tahun 2012. Business Accounting Review, 2 (2), hal. 151-159.

Nugroho, Bhuono Agung, 2005. Strategi Jitu Memilih Metode Statistik Penelitian dengan SPSS, Yogyakarta: Penerbit Andi.

Peraturan Otoritas Jasa Keuangan Nomor 29/POJK.04/2016 tentang Laporan Tahunan Emiten atau Perusahaan Publik http://www.ojk.go.id/id/kanal/pa sar-modal/regulasi/peraturanojk/Documents/Pages/POJKLaporan-Tahunan-EmitenPerusahaan-Publik/POJK-
Laporan-

Tahunan.pdf\#search=penyampai an\%201aporan\%20tahunan, diakses 03 Oktober 2016

Petronila, Thio Anastasia. 2007. "Pengaruh Faktor Internal dan Eksternal Perusahaan terhadap Audit Report lag dan Timeless". Jurnal Akuntansi dan Keuangan. Vol. 10. No.1. Mei. Hlm. 1-10.

Prabandari, Jeane Deart Meity dan Rustiana. 2007. Beberapa Faktor yang Berdampak pada Perbedaan Audit Delay (Studi Empiris Pada PerusahaanPerusahaan Keuangan yang Terdaftar di BEJ). Jurnal Kinerja. Vol. 11. Hlm. 27

Priyatno, Duwi. 2012. Cara Kilat Belajar Analisis Data dengan SPSS 20. Edisi Kesatu. Yogyakarta: Andi.

Rachmawati, Sistya. 2008. "Pengaruh Faktor Internal dan Eksternal Perusahaan Terhadap Audit Delay dan Timeliness". Jurnal Akuntansi dan Keuangan Vol.10 No.1 Mei 2008. Hlm.1

Ratnawaty and T. Sugiharto, 2005, "Audit Delay pada Industri Real Estate dan Properti yang Terdaftar di Bursa Efek Jakarta dan Faktor yang Mempengaruhinya", Proceeding Seminar Nasional PESAT, 288300

Ristin, Fika. 2016. Faktor-Faktor yang Mempengaruhi Audit Delay pada Perusahaan Manufaktur di Bursa Efek Indonesia. Universitas Hasanuddin.

Rochimawati. 2011. Analsis Diskriminan Audit Delay Pada Industri Keuangan Di Bursa 
Efek Indonesia (BEI). Skripsi. Universitas Gunadarma. Hlm 3.

Salinan Surat Edaran Otoritas Jasa Keuangan Nomor 30/SEOJK.04/2016 tentang Bentuk dan Isi Laporan Tahunan Emiten atau Perusahaan Publik http://www.ojk.go.id/id/kanal/pa sar-modal/regulasi/surat-edaranojk/Documents/SAL\%20-

\%20SEOJK Laporan\%20Tahun an\%20Emiten.pdf\#search=lapor an\%20tahunan\%20audit, diakses 01 Oktober 2016

Sanusi, Anwar. 2011. Metodologi Penelitian Bisnis. Jakarta: Salemba Empat.

Setiawan, Heru. 2013. Pengaruh Ukuran Perusahaan, Reputasi Auditor, Opini Audit, Profitabilitas dan Solvabilitas terhadap Audit Delay pada Perusahaan Keuangan yang Terdaftar di Bursa Efek Indonesia periode 2009-2011. Skripsi. Fakultas Ekonomi dan Bisnis Universitas Islam Negeri Syarif Hidayatullah Jakarta.
Subekti, Imam. dan N.W. Widiyanti. 2004. Faktor-Faktor Yang Berpengaruh Terhadap Audit Delay di Indonesia. Simposium Nasional Akuntansi VII:9911002.

Undang-undang Nomor 21 Tahun 2011 tentang Otoritas Jasa Keuangan http://www.ojk.go.id/id/regulasi/ otoritas-jasa-keuangan/undangundang/Pages/undang-undangnomor-21-tahun-2011-tentangotoritas-jasa-keuangan.aspx, diakses 03 Oktober 2016

Yulianti, Ani. (2011). Faktor-faktor Yang Berpengaruh Terhadap Audit Delay (Studi Empiris Pada Perusahaan yang Terdaftar di Bursa Efek Indonesia Tahun 2007-2008). Skripsi. Universitas Negeri Yogyakarta. 